\title{
山水画の構成手法と池泉鑑賞式庭園の景観構成に関する研究
}

\section{The Configuration Method of Landscape Painting and the Landscape Composition of Viewing Pond} Gardens

真木 利江* 柴 惟史**

Rie MAKI Tadafumi SHIBA

Abstract : This paper is a part of the research intends to shed light on the model of ideal scenery in Muromachi period. The aim of this paper is to clarify weather the landscape painting affected the landscape composition of viewing pond gardens in the period. There are eight gardens still exist, and each garden consists of upper part with main stone arrangements and lower one with pond in common. The landscapes of gardens are analyzed by the arrangement of garden elements according to the line of view. In consequence, we have following two distinct types of landscape composition: 'diagonal type' and 'orthogonal type'. Five gardens of 'diagonal type' are characterized by the composition that stone arrangements lined along diagonal vector show the unification of garden elements. Three gardens of 'orthogonal type' show the vector toward the artificial hills in the center contrasts garden elements lined horizontal. Each spatial composition is illustrated with isometric projection, and considered by comparison to two configuration methods of landscape paintings: 'three perspective drawing' and 'one corner' composition.

Keywords: Muromachi period, Landscape painting, viewing pond garden, landscape, type, composition キーワード：室町期, 山水画, 池泉鑑賞式庭園, 景観, 類型, 構成

\section{1. はじめに}

本稿は，山水画の構成手法が室町期に作庭されたとされる池泉 鑑賞式庭園の構成にみられるかどうか，その可能性を検討するこ とを目的としている。

室町期における庭園の姿は，会所を中心とした連歌・水墨画・ 生花等の文芸的社交，その中心の一つを形成していた中世禅宗寺 院の塔頭, 書院造の発展等と重ね合わされ理解されている。山水 は多様な文化的営みに通底する主題の一つであった。当時, 庭園 形式が池泉廻遊式から鑑賞式1) 人と移行するとともに枯山水が発 展するが，庭園史の分野ではその際に山水画が作庭へ多大な影響 を与えたと広く概説されている。とくに残山剰水の理念が縮景志 向とともに紹介されることが多く, 山水画の具象的表現としての 大仙院庭園に対し抽象的表現としての竜安寺庭園という例示が定 式となっている2)。しかし，その造形的な関係を具体的に問う研 究は十分に蓄積されていない。

室町期庭園に関するまとまった研究としては，まず外山英策に よる文献研究 ${ }^{3)}$ そして重森三玲（以下，重森）らによる庭園の実 測と観察にもとづいた研究4) 5)があげられる。また, 枯山水庭園に ついは様々な観点から調査・分析・考察が試みられており ${ }^{6)}$, 池泉廻遊式庭園に関しても，現存例が少ないものの発掘調査等に より新たな知見が示され，その成果をふまえた研究も重ねられて (る7)。しかし池泉鑑賞式庭園については重森らによる研究以降, まとまった研究はほとんど行われていない8

本稿では山水画が作庭に影響を与えた可能性を，造形的な類似 性という観点から検討する。そこでまず美術史分野で明らかにさ れている山水画の構成手法をとりあげ，庭園への敷衍可能性につ いて検討を加える。次に室町期に作庭されたとされる池泉鑑賞式 庭園を対象として, 景観構成類型の抽出を試みる。最後に抽出し た庭園の景観構成類型と山水画の構成手法を比較し考察を加え結 とする。

\section{2. 山水画の構成手法}

本稿では美術史分野で広く知られている山水画の構成手法とし て, 北宋画に由来する三遠と南宋画に由来する辺角の景をとりあ げる9)。

\section{（1）三遠}

まず，高遠・深遠・平遠からなる三遠は，郭熙によって論ぜら れた遠近法で, 北宋を中心に発達したとされる。図一 1 左に一幅 の中に三遠が描かれた代表的作品である郭熙による『早春図』を 示した。中央上部の山嶺が高遠，右下の山譬奥に滝が描かれた部 分が深遠, 左中段の水平に広がる地形の部分が平遠にあたる。三 遠については構図法として捉えるもの，それぞれを仰角視・鳥㒈 視・水平視といら視点場と視対象の高さ関係に対応するとするも のなど, 複数の解釈が示されているが, 最も素直な理解は山水画 が描出すべき山水の空間を三つにまとめたとするものであり，上 下・前後・左右という空間の 3 方向の拡がり，山水の高さ・深さ・ 広さの表現に対応するとされている ${ }^{10)}$ 。この理解に立つとき三遠 は, 山水画に限らず風景の表象を志向するあらゆる造形作品に敷

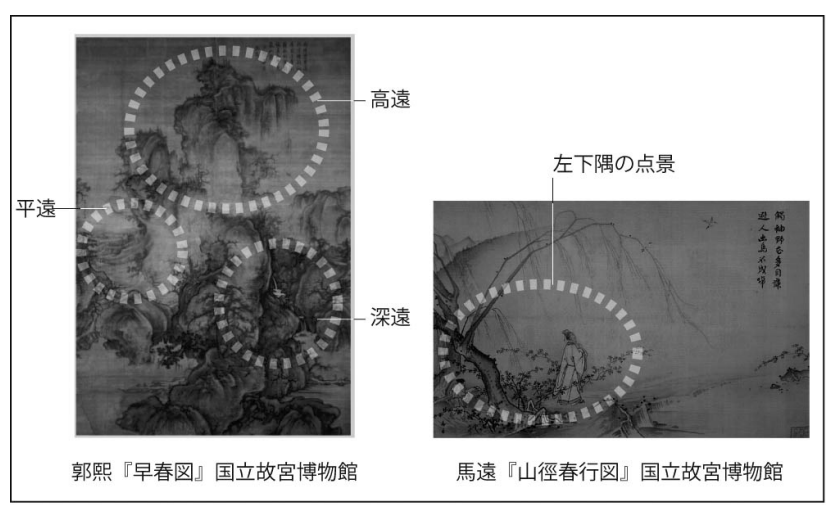

図一 1 三遠と辺角の景

*広島女学院大学人間生活学部 **フリー 
衍することが出来，池泉鑑賞式庭園も含まれる。本稿では庭園の 分析において眺めの中に捉えられる空間の 3 方向の拡がりに検討 を加えることとする。

\section{（2）辺角の景}

辺角の景は主に南宋画院の馬遠や夏珪によって使われた画面形 式として知られており，北宋の全景山水に対し南宋で発展する点 景山水の構成を指寸。図一 1 右に馬遠による『山徑春行図』を示 した。画面の左下隅に風景のごく一部が描かれ，それ以外が余白 とされている。辺角の景はこのように，点景を画面の左下または 右下隅に寄せて描き，中央や上方部分の多くを余白とする配置が 特徵的で, この余白による視覚的余韻によって鑑賞者に詩情を喚 起させる。画面の対角線両端の位置にそれぞれ点景を配し，中央 を余白とする配置もこれに含まれる。作庭と山水画を結ぶときに しばしば用いられる残山剰水はもともと江南地方の「敗残亡国の 山水」を意味するが, この画評語としての意味が辺角の景であり， 辺角の景で隅に配置される点景が残山剩水として捉えられる ${ }^{11}$ 。

また，辺角の景は，絵画におけるより広義の構成手法である対 角線構困に含まれる。対角線構図とは，画面の対角線またはそれ に近似する斜線上に要素を配置することで動態を創出する構図で ある。対象も風景に限定されず，遠近・リズム・明暗・色相の対 比や強弱と組み合わされることで，より効果的な動態12)が創出さ れる。辺角の景は対角線構図の特徵である斜線上の要素配置に加 え, 余白による視覚的余韻を特徵とする構成手法である。

本稿が主題とする造形的な観点から辺角の景を庭園に敷衍する とき，例えば庭園の眺めの中で隅に石組が配置され，その他は水 面や白砂が広がる等が想定され，三遠と異なり具体的で個別的な 造形手法といえる。

\section{3. 池泉鑑賞式庭園の構成}

\section{(1) 分析の対象}

本稿では重森他著『日本庭園史大系』で室町期の池泉鑑賞式の 庭として扱われる 12 庭園のうち, 当時の地割と石組をおおむね 残していると考えられ，かつ現地調查が可能な 8 庭園を対象とす る。保国寺庭園 (愛媛県西条市), 旧秀隣寺庭園 (滋賀県高島市), 旧玄成院庭園（福井県勝山市), 小川氏庭園（島根県江津市), 唯 念寺庭園（滋賀県犬上郡豊郷町），旧亀石坊庭園（福岡県田川郡添 田町), 万福寺庭園 (島根県益田市), 医光寺庭園 (島根県益田市) である ${ }^{13)}$ 。これら 8 庭園はいずれも書院等の建物から眺められる ことを主体とした池泉を持つ庭園である ${ }^{14)}$ 。池泉の奥には山畔利 用や築山の造成により，建物からの視線が受け止められるような 立体的構成を持っている。山畔や築山には主要な石組が施され, 眺めにおける焦点の一つをなしており，池泉にはいずれも滝石組 が組まれ，中島や出島により変化が与えられ石組が点在する。

各庭園の分析において，まず先行研究と現地調査にもとづく現 在の庭園を照らし合わせ，必要な場合には現状の荒廃部に対し当 時の庭園の想定を行う ${ }^{15)}$ 。次に先行研究で示される建物の推定位 置を参照し，8 庭園の書院方向からの眺めを対象として景観構成 の分析を行い，構成の共通性・相違性に注目することで景観構成 類型の抽出を試みる ${ }^{16)}$ 。なお, 現在, 各庭園ともに樹木・樹林・ 灌木等が眺めの中に現れるが，当時の庭園植栽の様子について史 実が明らかなものはなく, 基本的に石組本意の庭園として扱う ${ }^{17}$ 。

\section{(2) 分析の方法}

庭園は限定された三次元空間の中に構成要素が配されたもので, その構成要素は大きく池泉や地面の起伏といった地形と, 石組や 建物等の人為的要素の 2 つに区分することができる。庭園のひろ がりが書院等の建物方向から眺められるとき, 眺める人の視線に

\begin{tabular}{|c|c|c|}
\hline \multicolumn{3}{|c|}{ 表-1 分析指標 } \\
\hline \multirow{2}{*}{$\begin{array}{l}\text { 構成 } \\
\text { 要素素 }\end{array}$} & 地形 & $\begin{array}{l}\text { 水面 } \\
\text { 地面（築山·山畔） } \\
\text { 出島等 }\end{array}$ \\
\hline & $\begin{array}{l}\text { 人為的 } \\
\text { 要素 }\end{array}$ & $\begin{array}{l}\text { 石組 } \\
\text { 建物（本堂、書院） } \\
\text { 橋等 }\end{array}$ \\
\hline \multirow{4}{*}{$\begin{array}{c}\text { 配置の } \\
\text { 様相 }\end{array}$} & \multirow{3}{*}{ 位置 } & 奥行：近景 / 中景 / 遠景 \\
\hline & & 水平 ; 左 / 中央 / 右 \\
\hline & & 垂直 : 上/中段 /下 \\
\hline & 様相 & 連続 / 断続 / 独立 \\
\hline $\begin{array}{l}\text { 空間の } \\
\text { 方向性 }\end{array}$ & \multicolumn{2}{|c|}{$\begin{array}{l}\text { 奥行: 奥行感 } \\
\text { 水平 : 広がり感 } \\
\text { 垂直 : 上昇·下降感 }\end{array}$} \\
\hline
\end{tabular}

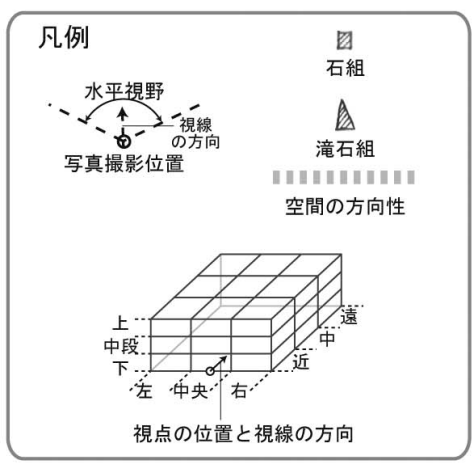

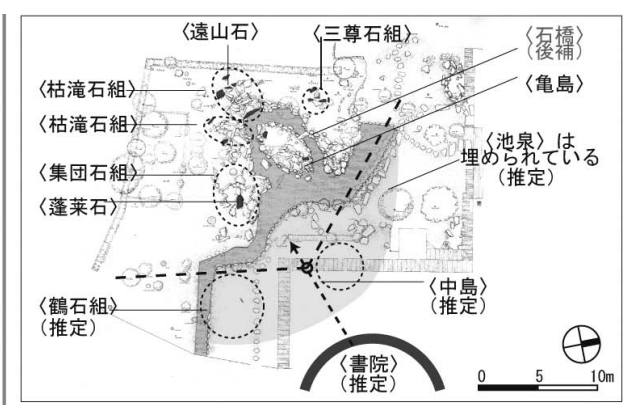
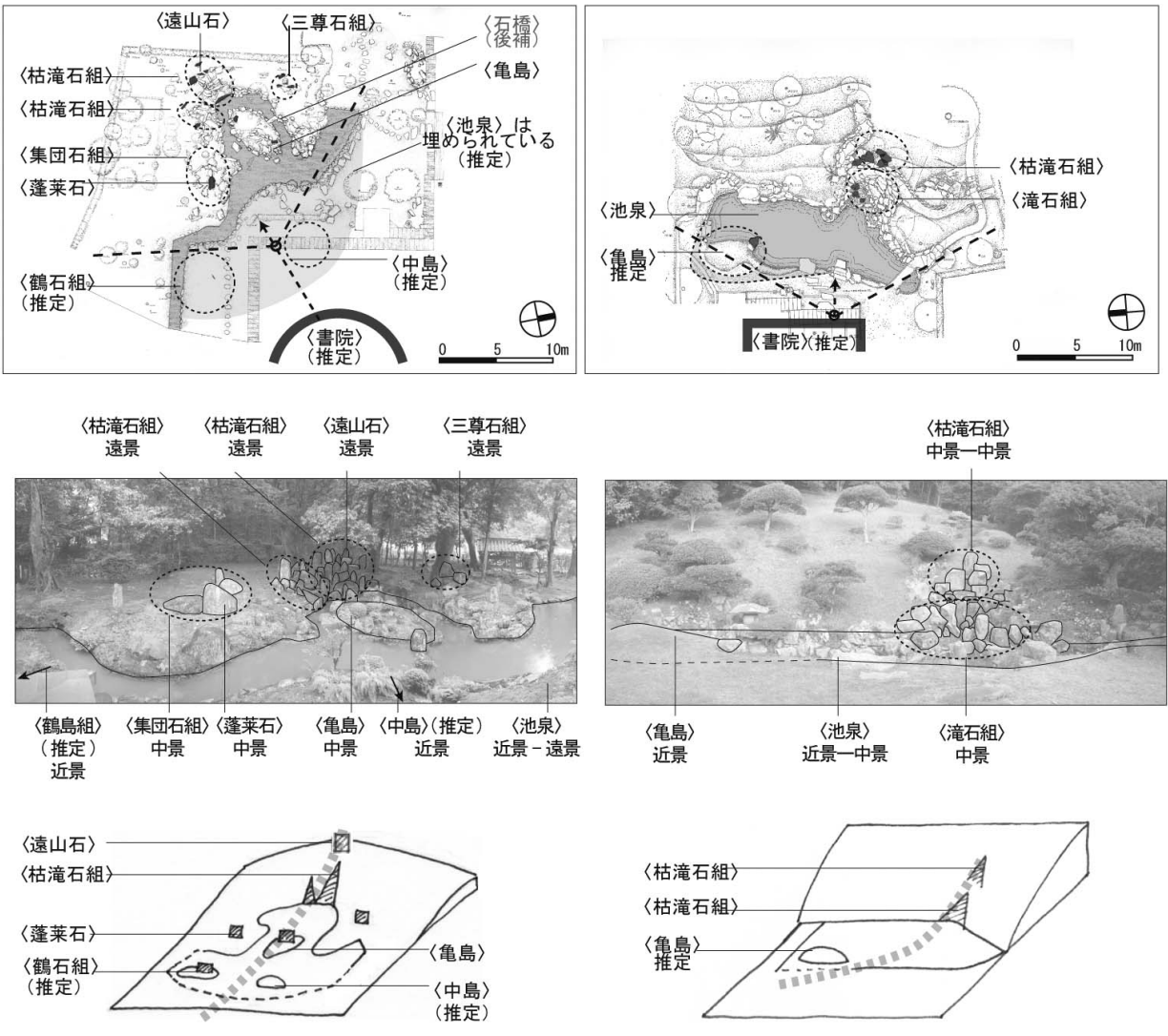

保国寺庭園

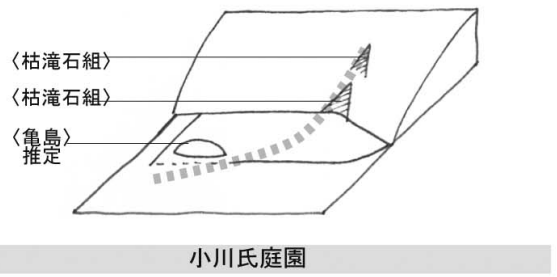

図一２庭園の景観構成分析 1 (平面図は『日本庭園史大系』より引用の上加筆、景観写真は筆者撮影の上加筆、模式図は筆者作成) 

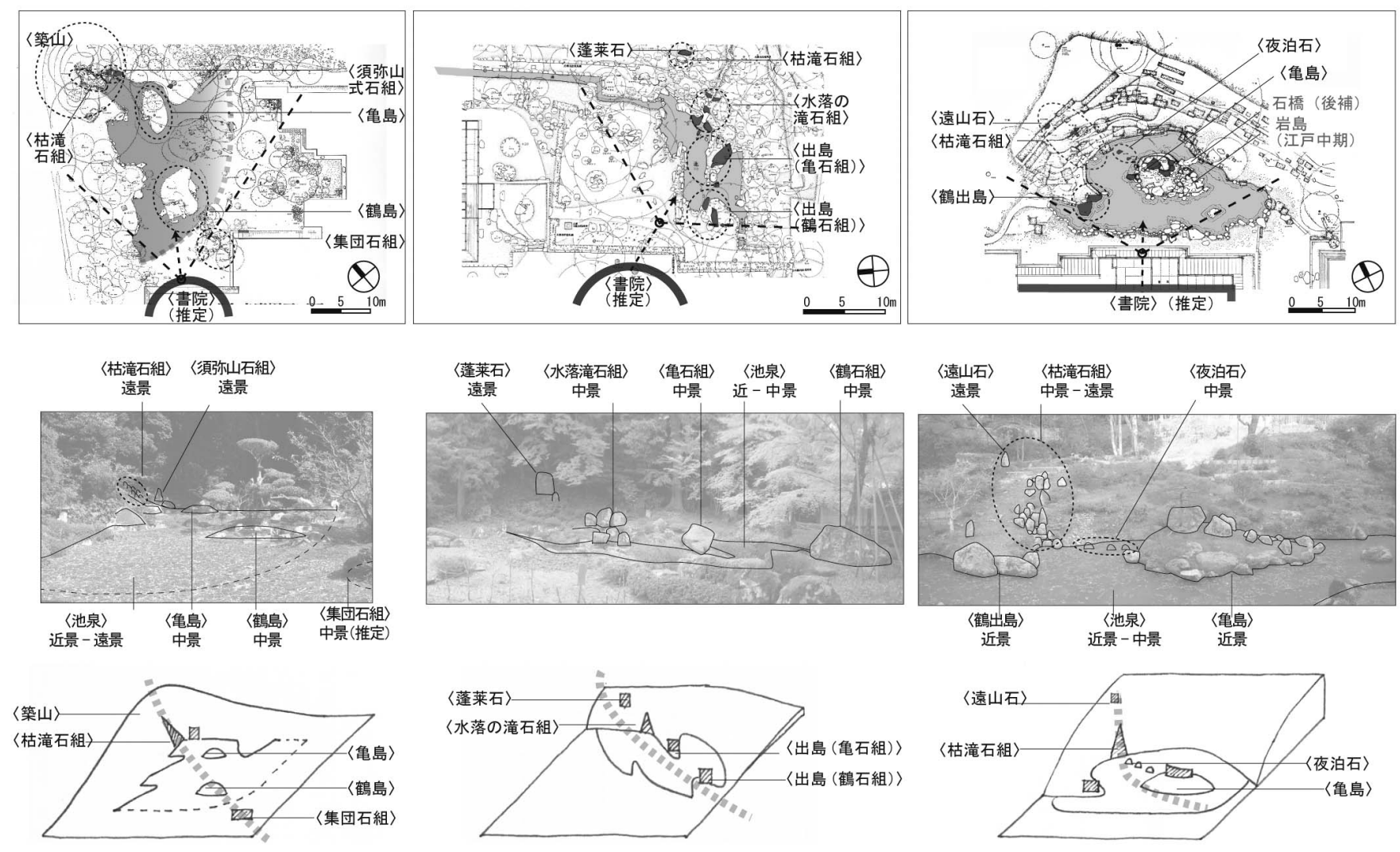

唯念寺庭園

旧亀石坊庭園

医光寺庭園
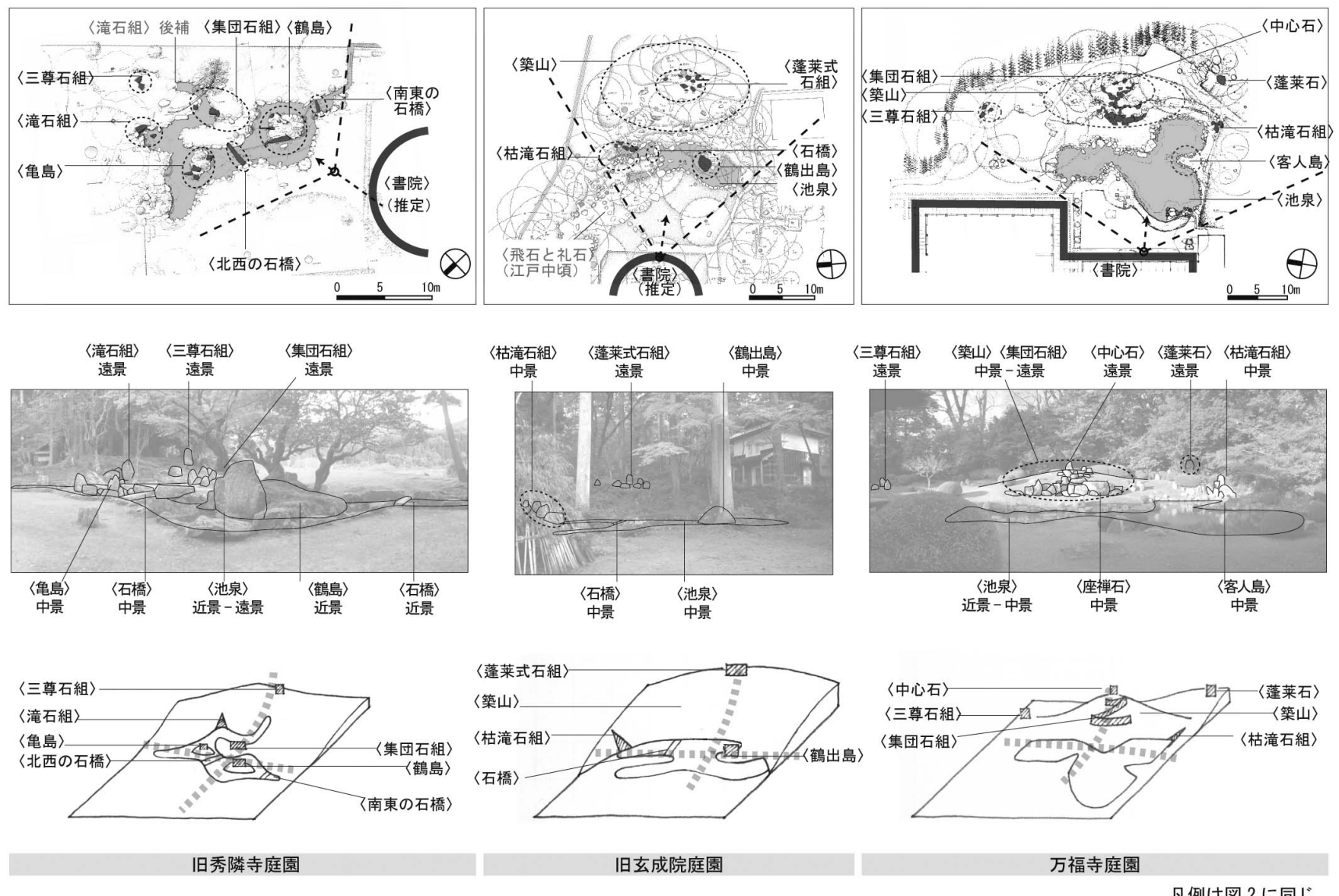

図一３庭園の景観構成分析 2 （平面図は『日本庭園史大系』より引用の上加筆、景観写真は筆者撮影の上加筆、模式図は筆者作成） 
対する位置関係が庭園要素に新たに付与されて眺めの中に現れる ことになる。眺めの中でこれらの構成要素は, 水平方向の右一中央 -左, 垂直方向の上-中段-下, 奥行き方向の近景-中景-遠景のなか に位置する。ここで奥行き方向は視線に対し，最奥部に位置する 庭園の構成要素を基淮とした相対的な距離とする。また庭園の構 成要素は庭園空間の広がりの中で，たとえば池が左から右へ連続 して広がる，複数の石組が手前から奥一断続的に連なる，他の要 素から離れ独立するなど, 連続・断続・独立といった様相を伴つ て捉え直される。これら要素の配置によって眺めには広がり感, 奥行感，上昇一下降感といった空間的動態が与えられる(表一 1)。

先行研究と現地調査にもとづき当時の推定を行った庭園の平面 図と景観, その分析を図- 2,3 に示寸。景観は写真で代替した ${ }^{18)}$ 。 また各庭園の配置の様相と空間の方向性をアイソノメトリック図 法により模式的に表現することを試みた。

\section{(3) 景観構成類型}

景観に現れる構成要素の配置の様相および空間の方向性の類似 性に着目すると，これらを大きく 2 つに分して捉える事が出来 る。庭園全体の方向性が手前の低い位置における広がりから左右 いずれか奥上方へと集約される＜対角線奥行型 $>$ と，手前低い位 置での左右方向の広がりと，中央上部奥への方向が直交する<中 央上昇・水平型>である。図 4 にそれぞれの類型のアイソメトリ ック図法によるモデル化を試み, 該当する庭園とともに示した ${ }^{19)}$ 。 対角線奥行型 : 保国寺庭園, 小川氏庭園, 唯念寺庭園, 旧亀石坊 庭園，医光寺庭園の 5 庭園が該当する。保国寺庭園をのぞく 4 庭 園では，左右いずれかに偏った位置に滝石組が配置され，池泉は これを頂点とする扇形または長方形に近似する形状で手前左右に 広がっている。手前下方では池泉が左右方向に連続して広がり， これが滝石組へ向かって収斂していく斜め奥上方への方向性がも

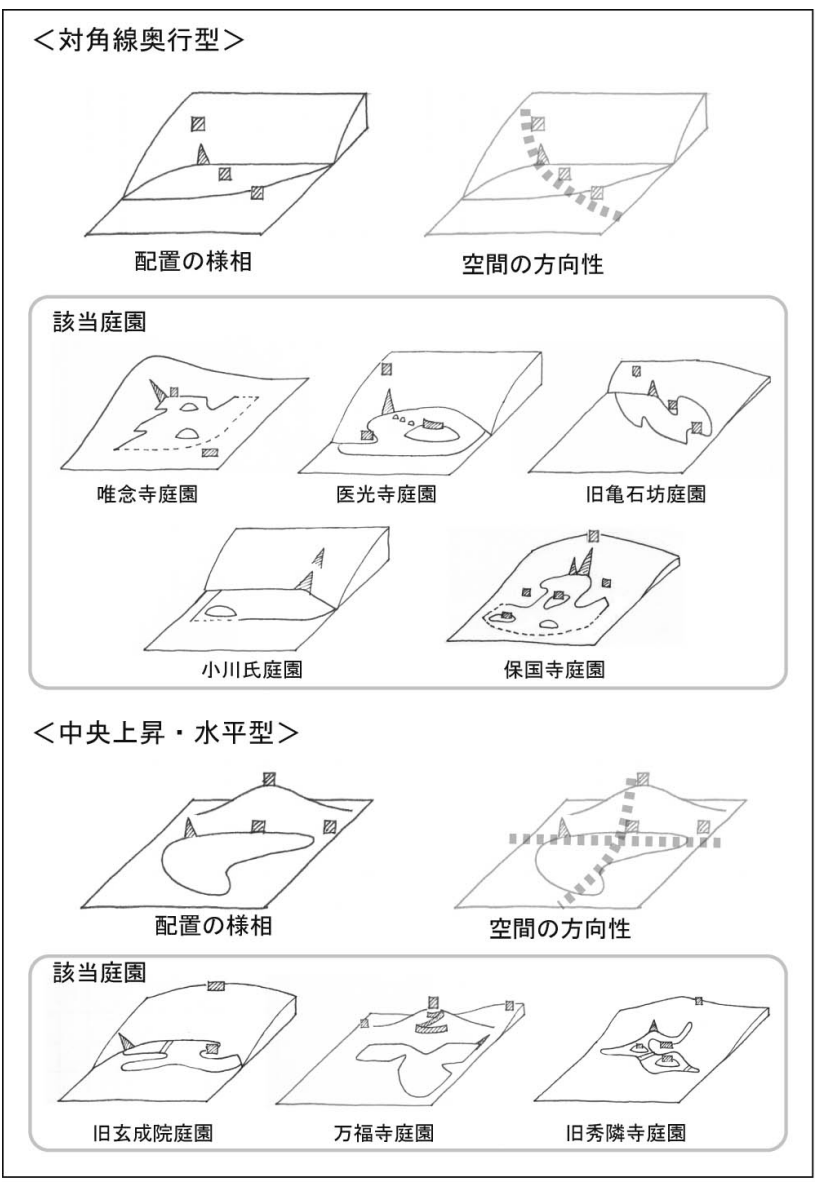

図-4 池泉観賞式庭園の景観類型
たらされている。いずれの庭園もこの方向性に沿って，池泉の広 がりを斜めに横切るように鶴亀島・出島等が断続的に配されて同 じくこの方向性を強調しつつ変化が与えられている。保国寺庭園 は滝石組が中央に位置している点を除くとほぼ同じ構成を見せる。 さらに医光寺，保国寺では滝石組の上部奥に蓬莱石が，旧亀石坊 では遠山石が配され，奥上方への方向性が強調されている ${ }^{20)}$

中央上昇・水平型 : 旧秀隣寺庭園, 旧玄成院庭園, 万福寺庭園で は，滝石組は左右いずれかに偏った位置に比較的低く組まれ，池 泉はやや変則的な形状を示しながら，左右方向の広がりを強調す る。池際に点在する石組もこれを強調している。一方，眺めの中 央上部奥, 築山上部または山畔の傾斜上部に, 旧秀隣寺では三尊 石組, 旧立成院では蓬莱式石組, 万福寺では中心石群が配されて いる。これらはそれぞれの庭園で最も遠くまた深い位置にある中 心的な石組で, 眺めの正面で立ち上がる地形とともに視線に沿っ て手前低、位置から中央奥上方への方向性を強調しており，池泉 による水平方向と対照をなしている。万福寺では二重に石組が重 ねられ, 旧秀隣寺では手前の鶴島から集団石組, 三尊石組と, 主 要な石組がこの方向性に沿うよう配されている21)。

\section{4. 考察}

池泉鑑賞式庭園の $2 つ の$ 景観構成類型について，＜三遠>およ びく辺角の景＞と比較し考察を加える。

\section{（1）三遠と景観構成類型}

三遠は上下・前後・左右という空間の 3 方向の拡がり, 山水の 高さ・深さ・広さの表現に対応するもので, 本稿ではこれを念頭 に置いて庭園の眺めに与えられる空間の方向性に注目して分析を 行った。

2 つの景観構成類型を空間の拡がり表現を整理すると，まずく 対角線奥行型>では，池泉の形状や石組の配置により左右いずれ かの下方手前から, 左右逆側の上方奥への空間的動態が卓越する。 この方向性は, 庭園空間の三次元的な広がりの対角線方向であり, この方向性に庭園要素の配置による空間の方向性が集約・統合さ れていると言える。これに対して，＜中央上昇・水平型>は高さ と深さが一体になった中央上方奥への方向性と左右の広がり方向 が重ね合わされ対比をなす構成として捉えられる。両者の高さ・ 深さ・広さ表現は大きく異なっている。

むろん，これをもってすなわち当時の作庭者達が空間造形とし て $2 つ の$ 構成類型を意図的に用いていたということはできないも のの, 山水画において古くから言語化され造形化されてきたく遠 さ>が，構成類型のうちに異なった型として具体化されている可 能性を指摘することが出来る ${ }^{22)}$ 。

\section{(2) 辺角の景と景観構成類型}

山水画における辺角の景は点景を画面の左右いずれかの下隅に 寄せて描き，広い余白が鑑賞者に視覚的余韻を与えるものであつ た。庭園では要素の配置されない水面や白砂が余白に当たると考 えられるが，<対角線奥行型 $><$ 中央上昇・水平型 $>$ のずれも 十分な余白を示しているとは言い難い。しかし類型を離れて8庭 園を個別に検討するならば，小川氏庭園では左手前の鶴島と右奥 の滝石組が中景の池泉を挟んで対置され，おおきく余白を挟んだ 対角線両端の石組配置となっている。

一方，2つの構成類型と辺角の景が含まれる対角線構図を比較 すると，<中央上昇・水平型＞との間に造形上の類似を見いだす ことは難しいが，＜対角線奥行型＞との間には強い相同性を指摘 することができる。左右いずれかの手前隅から反対側の奥上方一 庭園要素が配置される様は，対角線上の要素配置が，遠近と組み 合わされた効果的な動態の創出といえる。これまで室町期の山水 画と庭園の関係は残山剩水の理念と縮景志向が両者を結ぶものと して紹介されてきた。もちろん庭園に配されるそれぞれの石組を， 
自然の断片表現つまり残山剰水と重祆合わせて論じることは可能 である。しかし，山水画と池泉鑑賞式庭園の造形的関係を具体的 に問うとき，＜対角線奥行型>は辺角の景ではなく，より広義の 対角線構図と強い照応を見せる絵画的な構成として理解すること ができる。

\section{補注及び引用文献}

1）室町期庭園に限らず日本庭園の様式呼称恃，時代・鑑賞形式・建築様式との対応 · 思想的背景など, 区分の指標によりまた研究者により相違がある。最も広く共有さ れている様式区分の一つに吉川需によって示された林泉庭園, 枯山水, 露地という 3 区分がある（吉川需 (1968) : 古庭園のみかた，第一法規出版。ここで林泉庭園 の下位に位置づけられている廻斿庭園または伵遊式庭園を江戸期の総合的庭園と し, 室町期の大規模庭園をこれに含めないとする見解が示され，巡遊式といら呼称 が紹介された。近年では，吉川と同様に迴遊式 (回遊式ををあくまで江戸期のもの とする見解がある一方で (小野健吉(2004)：日本庭園辞典 : 岩波書店)，この 3 区 分を出発点としながら林泉庭園 (池庭, 池泉庭園) を鑑賞形式によって池泉舟遊 式「池泉回遊式「池泉鑑賞式「流水鑑賞式（曲水式」とするもの (西桂 (2005) : 日本の庭園文化 歷史と意匠をたず称て：学芸出版社），同様に「池心式「「舟遊式 「迴遊式「鑑賞式 等とするもの (斉藤忠一(1978): 名庭鑑賞辞典: 池泉: 探訪日 本の庭 七，小学館，168-173）もみられる。本稿では後者の鿟称従った。

2) 森榅(1993) : 日本史小百科 庭園: 東京堂出版/小野健吉(2009) : 日本の庭園-空間 と美の歴史 : 岩波書店他。

3) 外山英策 (1973 復刻) : 室町時代庭園史 : 思文閣出版

4) 重森三玲(1936-39): 日本庭園史四鑑: 有光社

5）重森三玲・重森完途 (1971-76) : 日本庭園史大系 : 社会思想社

6) 大山平四郎(1970)：竜安寺石庭 七つの謎を解く: 講談社 $/$ 宮元健次(2001) : 龍安 寺石庭を推理する : 集英社/宮江介他(2007) : 枯山水庭園の石庭における5・7・9 石石組の配石原則に関する研究 : ランドスケープ研究70(5)，491-496 他。

7）近年, 各地で発掘調查が進んでいる。例えば慈照寺庭園, 常栄寺庭園では部分的な 発掘調榃及ひ報告が行われている。京都市埋蔵文化財研究所編(2003): 京都市埋蔵 文化財研究所発掘調查概報 2003-01 史跡 慈照寺(銀閣寺) 旧境内: 京都市埋藏文化 財研究所/山口市教育委員会文化課編 (1997) : 山口市埋蔵文化財調査報告第 66 集常栄寺: 香山常栄寺, 山口市教育委員会。これら発掘調查の知見に基づく研究と して飛田紀夫(2006) : 庭園の中世史 足利義政と東山山荘 : 吉川弘文館/拙稿 (2011) : 常栄寺庭園にみる室町期の景観構成の特徴に関する研究: ランドスケープ 研究 74 (5)，375-378。慈照寺庭園は，当時と現況が大幅に異なる可能性が指摘さ れている。

8）池泉鑑賞式庭園に関する具体的な先行研究については後述。

9）山水画の構成手法については主に次の文献を参照した。王耀庭(1995) : 中国絵画の みかた : 二玄社 $/$ 新藤武弘(1989) : 山水画とは何か 中国の自然と芸術 : 福武書店 /平凡社編(1984-1991) : 平凡社 大百科事典 : 平凡社/石田尚豊他監(1987) : 日本 美術史事典 : 平凡社/秋山光和他編(1985) : 新潮世界美術辞典 : 新潮社

10）三遠は郭熙（1020 頃-90 頃）の子である郭思によって編まれた『林泉高致』(北宋 11 世紀頃)で論じられたもの。三遠の理解こついては, 次を参照した。島尾新 (2010) : 水墨画の歷史を語る 郭熙の「三遠法」と《早春図》: 趣味の水墨画, ユ 一キャン 2010 年 5 月号, 34-39/黒田正巳(1992) : 空間を描く遠近法, 彰国社/ 佐藤康邦(1992) : 絵画空間の哲学: 思想史の中の遠近法, 三元社。島尾は『林泉高 致』の「山に三遠あり。山下よりして山顛を仰ぐ，これを高遠という。山前よりし て山後を窥う，これを深遠という。近山よりして遠山を望む，これを平遠という」 という箇所のみがしばしば引用されることが問題で, 前後を総合すると「山水画が きちんと描出す心゙き空間を三つにまとめた」という理解になるとしている。また「三 遠」を「三遠法」と法則として理解する呼称にも疑問が示されている。当時, 三遠 が日本の山水画でどのように理解され実践されていたかは明らかれなっていない。 また, 三遠の遠さは単なる空間的な問題ではなく精神の深さの反映として理解す心゙ きとする見解もある。源豊宗(2006)：日本美術の流れ：新思索社

11)このことから残山剩水の理念と縮景志向が庭園と山水画を結ぶものとして紹介さ れるものと思われる。残山剩水の理念をあらゆる断片的表現に対応させて理解する ことは可能であるが，本稿では辺角の景の造形的な型としての側面を扱う。

12）対角線構困は絵画表現そのものが動態（運動，ムーブメント）の印象を喚起する形 式の一つで, 曲線や不均斉な配列など不安定な感じを引き起こす構成の一つである。 絵画におけ対角線構龱が示寸動態は必ずしも空間的ではない。竹内敏雄偏 (1961) : 美学事典: 弘文堂, 244-245
13）重森, 前掲 5 で室町期の庭園を扱った $5,6,7$ 巻による。庭園名称もこれに倣った。 重森, 前掲 4 ではこのうち6 庭園か浙収されており, 必要に応じて参照した。本稿 で扱わない 4 庭園は旧西方院庭園（広島県廿日市市），旧鈴木三郎居館庭園（和歌 山県海南市), 旧大寺 (伊藤氏) 庭園 (兵庫県南あわじ市), 北香神社庭園 (三重県 津市) である。旧西方院庭園は現在非公開である。旧鈴木三郎居館庭園は細川高国 による曲水式庭園である可能性が指摘され，文化財的価值が高い庭園の一つとされ るが, 重森䧓時にすでに池泉が枯れ，石組のほとんどが失われる等の荒廃が進ん でいる。旧大寺庭園も, 重森の調查時にすでに相当の荒廃が進んでいると報告され ているが, 阪神淡路大震災後も手入れされることなく放置された状態で，さらに荒 廃が進んでいるものと推定される。

北畠神社庭園は管理の行き届いた美しい室町期庭園の一つである。重森は蓬莱曲 水池泉鑑賞式としているが（前掲5），庭園は三千平米ちかくにひろがり池泉廻遊 式とする見解もある (大橋治三, 斎藤忠一編(1998)：日本庭園鑑賞辞典 : 東京堂出 版)。重森の調查以降, 部分的であるものの発掘調查も行われている。三重県美杉 村教育委員会編 (2002)：北香氏館跡6 名勝及び史跡北畠氏館跡庭園 記念物保存修 理報告, 美杉村教育委員会。そこで 2010 年 7 月と 12 月に現地調査と文化財担当者 等へのヒアリングを行い池泉鑑賞式庭園に含めないこととした。

重森の研究は, 現在の庭園史分野における編年の基礎になっているものの, その 後の発掘調査や文献史学の進展により, 疑義が示されている庭園もある。刘象庭園 に関する重森以降の調査研究は次の通りで, 文献の解积や作庭手法に関して重森と 異なった見解を示寸ものもあるが，庭園構成に関わる新しい史実や決定的な論考は 示されていない。また医光寺庭園でも発掘調查・修復工事が行われており 2012 年 度に報告書が作成される予定である。対象とする8庭園のいずれも，室町期の作庭 を直接に裏付ける史料は現存せず, また程度の差があるもののいずれも荒廃が進ん でおり，当時の庭園と現状との間に相違が指摘されている。

旧秀隣寺庭園: 実測調查図が次に所収され，部分的に重森と異なった見解が示され ている。朽小村史編さん委員会編(2010): 朽村史資料編 朽木の文化財 5 池の 沢庭園と旧秀隣寺庭園: 滋賀県高島市。また庭園を含め周辺地域の発掘調查等が進 められているが，庭園部の発掘は行われていない。滋賀県教育委員会編（1991）： 滋賀県中世城郭分布調查 8 高島郡の城: 滋賀県教育委員会/高島市教育委員会編 （2009）：高島市内遺跡調查報告書：滋賀県高島市，高島市教育委員会

旧玄成院庭園: 実測調查図が次に収められている。福井県編 $(1989)$ : 福井県史 資 料編 14 建築・絵画・彫刻等: 福井県。また白山神社平泉洸宮司による研究が次 にまとめられている。平泉百合子他編 (1998) : 平泉洸 遺稿集

小川氏庭園 : 江戸初期の書院の移築に伴い, 試掘が行われている。江津市教育委員 会(2006) : 小川庭園郵完䟞試掘調查報告書 : 江津市

旧亀石坊庭園: 英彦山地区の保存施策の資料収集を目的とした調査が行われており， 実測図も收められている。福岡県文化課・添田町社会教育課編(1978) : 山伏の住む 英彦山一英彦山伝統的建造物群保存地区調查概要 : 添田町教育委員会

14) 重森の研究は用語使用や論理構成に混乱が見られることが知られているが，刘象と する 8 庭園の样式名称については一貫性がない。万福寺庭園と医光寺庭園は䢐遊兼 鑑賞式または鑑賞兼廻遊式とされるが，具体的な迴遊路の指摘よ全く行われていな い。一方，場合保国寺庭園・旧秀隣寺庭園・旧立成院庭園については曲水式と指摘 されている。旧立成院庭園に関しては, 他の研究（福井県編，前掲9）で回遊式枯 山水庭園として紹介されており，2 通りの巡路が示されている。これらの庭園につ いて,われわ机は当時の鑑賞者か鑑賞庭園内に降り立ち, 䞟遊を伴ってまた曲水の 宴の用途に供し鑑賞した可能性を否定しないが，基本的には晝院（建物）からの鑑 賞が共通寸る大きな主題になっていたという仮定に立つ。

15)平面図中に現存寸る当時の石組と考えられているものを濃いグレーで示したが, 護 岸石組については現存石組が部分的であることが多いため, 池泉形状を示すことで 代用し表示を省いた。

各庭園について, 先行研究で指摘される現状と異なる当時の可能性のうち景観分析 に関連する内容と，それに対する想定をまとめておく。基本的に重森の想定にもと づたが, 判断が難しいものは現状を優先した。

保国寺庭園 : 重森, 前掲 5 , 第 5 巻, 31-40/前掲 4, 第4巻, 24-30, および 2010 年 10 月の現地調查による。亀島一架かる石橋は手法から後補のものと考えられて いる。作庭当時は現在より晝院が東に位置し, より広い池泉が広がり, 中島・鶴島 が浮かんでいたと考えられている。これらの正確な位置は不明であるが, 本稿では これらの見解こならい，おおよその位置を仮定した。

旧秀隣寺庭園 : 重森, 前掲 5 , 第 5 巻, 87-96/前掲 4 , 第 3 巻上, $64-70$ および前 揭 9 の資料，2010 年 11 月の現地調查・ヒアリングにもとづく。まず，現地で庭 園が北東側一約 2 倍の広がりを持っていたとする見解もあるが現状に従った。庭園 
を鑑賞する書院位置は庭園の南西部とするもの（重森，前掲 5,90 ), 庭園西部と 寸るもの（朽村史編さん委員会，前掲 9，94）で見解が分かれるが，現地では非 公式な発掘調査により土器が発見された経緯からも南西部が支持されており, 本稿 でもこれにならった。現存石組については重森の見解にならった。

旧玄成院庭園 : 重森, 前掲 5, 第6 巻, 119-126, および前掲 9 の資料, 2010 年 11 月の現地調査・ヒアリングにもとづく。重森の指摘と県史（福井県，前掲9）での 指摘に乘離の大きい庭園であるが, 書院位置は共通して東側の建物跡付近と考えら れている。池は重森の指摘に従い, 水が張られていたと想定している。その他石組 に関する考え方も重森の見解に従ったが, 県史では鶴出島が岩島であった可能性等 も指摘されている。

小川庭園 : 重森, 前掲 5 , 第 7 巻, 3-10/前掲 4 , 第 3 巻上, $70-75$, および前掲 9 の資料, 2010 年 11 月の現地調査・ヒアリングにもとづく。重森は, 当時は池泉 がより西側に広がって州浜をなし,亀頭石のある池泉北西の出島が亀島だったと指 摘している。2006 年の試掘時, 重森の見解を念頭に置いた調査が行われたが, 否 定する結果は得られていない。現在の書院建物は重森調査時より西へ約 $3 \mathrm{~m}$ 位置が 動かされている。本稿では晝院位置は現在と同等の位置, 池泉は西にやや広がって 亀島を浮がてていたと想定した。池泉がさらに広かった可能性もある。

唯念寺庭園 : 重森, 前掲 5 , 第 7 巻，11-18／前掲 4 ，第 4 巻，30-33，および 2010 年 11 月の現地調查・ヒアリングにもとづく。本稿で取り上げる 8 庭園の中で最も 荒廃が進んでいる庭園であり, 重森以外のまとまった調査研究は存在しない。重森 はこれを池泉庭園と位置づけているが, 現地では古来, 水利に恵まれない土地であ ることから疑問視する意見も聞かれた。重森は意匠的特徵から室町初期の作と位置 づけて当時の庭園の姿を想定しており, 本稿ではこれらに倣う。

旧亀石坊庭園 : 重森, 前掲 5 ，第 7 巻，37-42，およひ前掲 9 の資料，2010 年 11 月の現地調査にもとづく。晝院位置についての見解が分かれている。重森は明記し ないものの, 庭園西側から眺めた形で庭園を記述している。これに対し, 後者は現 在建物が建っている北側に坊舎があったとするが, 根拠は示されない。本稿では重 森が庭園を眺める位置に晝院を想定した。

万福寺庭園: 重森, 前掲 5 , 第 7 巻, 43-50/前掲 4 , 第三巻下, 41-49, および 2010 年 4 月 12 月の現地調査にもとづいた。北部の三尊石組周辺により多くの集村石組 があった可能性が指摘されているものの, ほぼ当時の様子を伝えていると考えられ ている。

医光寺庭園 : 重森, 前掲 5，51-58／前掲 4, 第三巻下，46-52，および 2010 年 4 月, 12 月の現地調査にもとづいた。次の文献では火災後, 建物が庭園側に拡張さ れたと指摘されており，書院位置が現在よりやや南に位置していたと想定した。白 石值典(2000) : 雪舟の庭 : 西日本出版社, 166-168/矢富嚴夫(1980) : 雪舟 : 雪舟 顕彰会, 65。石組等については亀島に架かる橋, 岩島は後補, 夜泊石は当時からと する重森の見解にならった。

16) 本稿では先行研究等で推定されている書院位置方向から庭園の全貌が眺められる よう, 現状で可能な範用で写真撮影し，これを対象として景観分析を行う。書院建 物は, 当時と現状の相違が大きくないと考えられている小川氏庭園, 万福寺庭園, 医光寺庭園の 3 庭園は方形で示したが, 当時の位置のみが推定されている残り 5 庭 園は, 庭園に対寸る建物の向きおよび規模が不明であるため, 室町期方丈建築の横 幅に当たる 7.5 間を目安として位置の表示とした。

17) 次のように植栽も重要な役割を果たしていたという指摘もある。小野健吉(2005)： フロイス『日本史』の記述から読み解く永禄 8 年(1565)の京都の庭園の形態と機 能 : ランドスケープ研究68(5), 369-72

18）写真は水平画角約 65 度のカメラで撮影したが，撮影可能な地点から庭園の全貌を 示寸ことが出来るよう，8庭園のうち旧立成院庭園と唯念寺庭園を 80 度, 他の 6 庭園は 120 度の水平視野になるよう画像をつなげて使用している。平面図上に撮影 地点と水平視野を示した。また視線の方向である水平視野の中央線を矢印で示し, 書院位置が当時と異なっていると推定され, 撮影地点と視点場である劃完建物の位 置が離れている庭園（保国寺庭園，旧秀隣寺庭園，旧亀石坊庭園）は，この矢印を 書院側に延長し位置関係を示した。水平・垂直方向の位置および連続・断続の様相 は明示されるため, 奥行方向のみ記した。また空間の方向性は図中の表示を省いた。 19）該当する庭園はモデルに近い庭園から上段右から左，下段右から左の順に並心゙た。 20）この方向性は景観構成分析及ひ模式化で基淮とした直方体の対角線にあたる。

21）ここで 2 類型と, 重森が示寸作庭時期およひ庭園様式との関係を記しておく。保国 寺庭園, 小川氏庭園, 唯念寺庭園の 3 庭園が室町初期に, 万福寺庭園, 医光寺庭園, 旧亀石坊庭園の 3 庭園が室町中期に, 旧秀隣寺庭園, 旧立成院庭園の 2 庭園が室町 末期に位置づけられている。＜対角線奥行型＞に該当寸る 5 庭園は初期 3 ，中期 2 庭園であり，<中央上昇・水平型 $>03$ 庭園は中期 1 ，末期 2 庭園である。時代を
下るにつれて景観構成が変化していった可能性も考えられる。また, 䞟遊式を兼ね る庭園が 2 , 曲水式が 3 庭園挙げられていたが（前掲, 9), <中央上昇・水平型 $>$ の 3 庭園は寸べてこれらに該当する。これは一方向からの眺めだけでなく, 別の地 点からの眺めが想定されていた可能性も考えられる。

22）両類型の滝石組位置の相違は型としての意識の相違を表しているようにも思われ る。山水画においても, 滝は観瀑図という画題が成立するほどしばしば描かれたモ チーフであるが, 8 庭園では寸べてで滝石組が組まれている。庭園に配される石組 は蓬莱, 鶴亀と言った意味と結ばれて当時の鑑賞者に捉えられていたが, われわれ がそれらの意味を正確に理解することは難しい。しかし, 滝石組と池泉といら構成 要素の関係は, 龍門瀑といった個別の意味をこえて, 水が高いところから低いとこ ろ一流れ込むという普遍的な関係が造形化されたものである。この滝石組と池泉の 結びうきがく対角線奥行型>では, 上部主要石組から池泉への一体的な関係に内包 されるのに対し，<中央上昇・水平型>では, 滝石組と池泉の連続的な関係と離れ た位置に上部主要石組が組まれ，これが直交する方向性の創出に寄与している。 